Agro-Science Journal of Tropical Agriculture, Food, Environment and Extension Volume 20 Number 2 (April 2021) pp. $42-48$

ISSN 1119-7455

\title{
PLANT POWDERS PROTECT STORED WHEAT FROM INFESTATION BY LESSER GRAIN BORER Rhyzopertha dominica (FABRICIUS) (BOSTRICHIDAE: COLEOPTERA)
}

\author{
${ }^{1}$ Negbenebor H.E., ${ }^{2}$ Makanjuola W.A. and ${ }^{* 3}$ Nura S. \\ ${ }^{1}$ Department of Computing \& Applied Sciences, Baze University, Abuja, Nigeria \\ ${ }^{2}$ Department of Zoology, University of Lagos, Nigeria \\ ${ }^{3}$ Department of Biology, Ahmadu Bello University, Zaria, Nigeria \\ *Corresponding author's email: salisunura40@yahoo.com
}

\begin{abstract}
Rhyzopertha dominica (Bostrichidae: Coleoptera) is one of the most serious devastating insect pests attacking stored wheat grains in Nigeria. The most common strategy adopted in controlling this insect pest is the application of synthetic pesticides which is costly, toxic to non-target organisms and is non eco-friendly. Botanical pesticides are recently used as alternatives to synthetic pesticides due to their non-hazardous effect on the environment and non-target organisms, cost effectiveness and direct impacts on the target organisms. This study was carried out to determine the toxicity of leaf powders obtained from three species of plants: Ageratum conyzoides, Momordica charantia and Tephrosia vogelii in the control of $R$. dominica infestation on stored wheat grains. Five doses $(0.50,1.00,2.00,4.00$ and $8.00 \mathrm{~g})$ per $20.00 \mathrm{~g}$ were measured from the powdered leaves of the tested plants with ethanol treatment as the control $\left(0.00 \mathrm{~g} 20.00 \mathrm{~g}^{-1}\right)$. The powdered doses were applied onto wheat grains before the insects were introduced. The experiment was laid down in completely randomized design (CRD) with three replications. The data obtained was analyzed using analysis of variance at 5\% probability level with Least Significant Difference used to separate the means. The results showed significant $(p \leq 0.05)$ differences in the magnitude of toxicity imparted by various doses of the powders on $R$. dominica. The treatments influence high rate of mortality, reduced number of laid eggs and emerged adults when compared with the control. The toxicity of the powders increased with increase in dosage. It was concluded that $8.00 \mathrm{~g} 20.00 \mathrm{~g}^{-1}$ of the powders were more toxic to $R$. dominica, inducing $28.00-77.30 \%$ insects' mortality thereby protecting grain damage to as low as $1.04 \%$ at $6^{\text {th }}$ month of storage. $T$. vogelii leaf powders were recommended for use against $R$. dominica in stored wheat grains.
\end{abstract}

Key words: botanicals, dose, lesser grain borer, wheat

\section{INTRODUCTION}

Wheat (Triticum aestivum) is the world's most important cereal crop in relation to production and consumption (Ileke, 2011). It is the most important cereal crop traded in the world and the most protein us grain consumed in developing countries to combat malnutrition (Ileke, 2011). Despite the significant importance of wheat to food security in Africa in general and Nigeria in particular, its storage is threatened by several insect pests (Adedire, 2001; Ileke, 2011). These insect pests cause significant losses to stored wheat. Storage loss due to insects' infestation was estimated to be up to $70 \%$ in developing countries (Strbac, 2002; Kavita, 2004). These insect pests cause quantitative and qualitative damage to grains (Fornal et al., 2007). One of the most serious devastating insect pests of wheat is the lesser grain borer (Rhyzophertha dominica).

Rhyzopertha dominica (Bostrichidae: Coleoptera) is one of the most devastating pests of stored grains both at larval and adult stage
(Raju, 1984). They impart economic losses in terms of grain mass (Subramanyam and Hagstrum, 1996) and nutrient depletion (Jood et al., 1996) and pose a public health risk from contamination by allergens such as uric acid (Jood and Kapoor, 1993). The most common control measure adopted in Nigeria against $R$. dominica infestation of stored wheat is the application of synthetic insecticides (Salem et al., 2007). These synthetic insecticides have negative consequences on the environment and other non-target populations including man (Adedire and Lajide, 2003; Adedire et al., 2011; Ileke and Oni, 2011; Udo, 2011; Ileke and Bulus, 2012; Ileke and Olotuah, 2012). Alternative strategy is needed to ameliorate these problems. Botanical insecticides were recently recommended in pests management strategies as they are cheaper, ecologically friendly and specific to the target organisms (Ashamo and Odeyemi, 2001: Oni and Ileke, 2008; Akinkurolere et al., 2009; Ileke et al., 2012). Ageratum conyzoides, Momordica charantia and Tephrosia vogelii were selected for this study

Please cite as: Negbenebor H.E., Makanjuola W.A. and Nura S. (2021). Plant powders protect stored wheat from infestation by lesser grain borer Rhyzopertha dominica (Fabricius) (Bostrichidae: Coleoptera). Agro-Science, 20 (2), 42-48. DOI: https://dx.doi.org/10.4314/as.v20i2.7 
due to their relative abundance within the vicinity of the local communities in Nigeria and are among the plant species reported to have insecticidal properties against insect pests of stored products (Adda et al., 2011; Olaniran and Adebayo, 2013; Ileke and Emmanuel, 2018; Emeasor and Ndumele, 2019). Thus, this study evaluated the insecticidal potency of three plants leaves powder against $R$. dominica infestation of stored wheat grains.

\section{MATERIALS AND METHODS Plant Materials}

Fresh leaves of Ageratum conyzoides (Compositae), Momordica charantia (Cucurbitaceae) and Tephrosia vogelii (Fabaceae) were obtained from vendors at Oyingbo market in Lagos, identified and authenticated in the Herbarium of the Department of Botany, University of Lagos, Nigeria. The voucher numbers: LUH 3295, LUH 3291 and LUH 2317 were assigned to the test plants respectively.

\section{Disinfestations of Wheat Grains}

Wheat grains were obtained from Bariga market, Lagos. They were identified as Triticum aestivum seeds at the Nigeria Stored Products Research Institute (NSPRI) Lagos, Nigeria. All damaged seeds and debris were sorted out from the grains after which disinfestations was carried out in an oven at $50^{\circ} \mathrm{C}$ for six hours to kill all life stages of insects within the grains. The grains were then left for 24 hours to stabilize at ambient conditions.

\section{Source of Insects}

One hundred adults of $R$. dominica were obtained from an already existing culture in the Entomology Laboratory of Nigeria Stored Products Research Institute (NSPRI) Lagos. Rearing of the insects followed the method described by Dabire et al. (2005). The insects were introduced into $500 \mathrm{ml}$ rearing bottles containing $300 \mathrm{~g}$ of disinfested wheat grains. The disinfested grains were then air dried in the laboratory to prevent fungal growth as described by Adedire et al. (2011) before introduction of insects. The bottles were covered with muslin cloth and secured with rubber bands. They were kept in an incubator for oviposition at $30^{\circ} \mathrm{C}$ and $70 \%$ relative humidity for 10 days after which the parents were removed. The bottles were maintained in the incubator under the same condition for adult emergence. Toxicity tests were carried out on $1^{\text {st }}$, $3^{\text {rd }}$ and $5^{\text {th }}$ instars larvae and adults of $R$. dominica. Wheat grains used for the experiment were also disinfested as described above before it was stored in plastic containers with tight lids.

\section{Multiplication of Insect Culture}

Rhyzopertha dominica were maintained on disinfested wheat grains. Thirty unsexed 7-14 day old adults of $R$. dominica were introduced into $20 \mathrm{~g}$ each of disinfested wheat grains in $1.00 \mathrm{~L}$ kilner jars, respectively, in three replicates in the laboratory. All adult insects were left for 10 days to allow for oviposition, after which they were removed. They were then left undisturbed until adults were observed to emerge. At each peak of emergence, the adults were removed and used to set up new cultures. Series of fresh cultures were made from these to ensure regular supply of adult insects of known ages for use in subsequent experiments.

\section{Preparation of Plant Powders}

The fresh leaves of the three test plants: $A$. conyzoides, $M$. charantia and $T$. vogelii were air dried at room temperature, pounded to fine powder with pestle and mortar according to the protocols described by Dabire et al. (2008). The powder was further sieved through $1.00 \mathrm{~mm}^{2}$ mesh as described by Ileke and Bulus (2012). They were packed in plastic containers with tight lids and kept in the dark according to the method described by Udo (2011).

\section{Experimental Design}

The plant powders obtained from $A$. conyzoides, $M$. charantia and $T$. vogelii were thoroughly mixed singly with $20.00 \mathrm{~g}$ of disinfested wheat grains in each of the six plastic containers at $0.50,1.00,2.00$, 4.00 and $8.00 \mathrm{~g}$ and manually agitated for uniform dispersal. The controls $\left(0.00 \mathrm{~g} 20.00 \mathrm{~g}^{-1}\right)$ were treated with ethanol. Thirty newly emerged unsexed $R$. dominica were randomly picked and released into each plastic container as well as that of the control and covered. The plastic pot was covered with thick paper to provide a favorable semi-dark environment to the lesser grain borer for egg deposition. Treatments were arranged in a completely randomized design with three replications. The containers were kept in the laboratory.

After 15 days, number of eggs laid on treated seeds and control seeds were recorded and the percentage of oviposition deterrence was calculated using Singh and Jakhmola (2011) formula:

\section{$\%$ Oviposition deterrence $=\underline{\text { Cs-Ts }} \times 100 \mathrm{Cs}$}

where Cs is number of eggs laid on control seeds, and Ts is number of eggs laid on treated seeds. Toxicity of the powders on the insects was determined by the rate of mortality induced by the powders on the insects. Insect mortality was observed daily for 2 days. After every 24 hours, the number of dead beetles were counted and recorded. The beetles were confirmed dead when there was no response to probing with sharp pin at the abdomen as described by Adedire et al. (2011). At the end of day 2, all insects, both dead and alive were removed from each container. The toxicity factor (TF) is calculated using the formula:

Toxicity Factor $(\mathrm{TF})=48 \mathrm{~h} \mathrm{LD}_{50}$ value of the least toxic compound $48 \mathrm{~h} \mathrm{LD}_{50}$ value of the more toxic compound. The experiment was kept inside the insect cage for another 30 days. The $R$. dominica 
started to emerge after 30 days of oviposition. The number of adults that emerged from each container per replicate were removed, counted and recorded each day for a period of 10 days.

\section{Insect Damage in Grains}

Each wheat grains were taken out from the plastic container to determine the presence/absence of feeding hole(s) on each seed. Seeds containing hole(s) was considered as damaged seeds. The number of damaged wheat seeds was counted and recorded for each treatment per replication. Monthly insect damage in each treatment and control was determined from $20.00 \mathrm{~g}$ batches of grains in each plastic container as described by Odeyemi and Daramola (2000):

Percentage weight loss $=\left(\underline{\mathrm{W}}_{\underline{\mathrm{u}}} \underline{\mathrm{x}} \underline{\mathrm{N}_{\mathrm{d}}} \underline{\underline{\mathrm{W}}}-\left(\mathrm{W}_{\mathrm{d}} \underline{\mathrm{xN}} \underline{\underline{\mathrm{u}}}\right) \times 100\right.$

$$
\mathrm{W}_{\mathrm{u}}\left(\mathrm{Nd}+\mathrm{N}_{\mathrm{u}}\right)
$$

where $W_{u}$ is weight of undamaged grains, $N_{u}$ is number of undamaged grains, $\mathrm{W}_{\mathrm{d}}$ is weight of damaged grains, and $\mathrm{N}_{\mathrm{d}}$ is number of damaged grains.

\section{Data Analysis}

The data obtained were analyzed using analysis of variance (ANOVA) using SPSS (11.0 versions) with Duncan's New Multiple Range Test (DNMRT) used to compare the treatment means. Lethal Dose of the powders is determined using Probit analysis.

\section{RESULTS}

The result on the relative toxicity of the three plant powders to $R$. dominica is presented in Table 1 . Tephrosia vogelii was the most toxic and produced

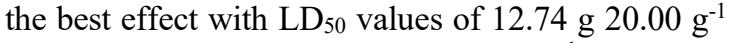

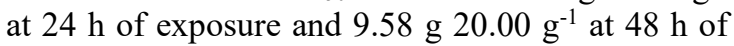
exposure. However, the powders of Ageratum conyzoides had the lowest $\mathrm{LD}_{50}$ value $20.09 \mathrm{~g}$

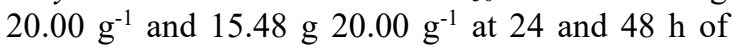
exposure respectively. The trend in the toxicity followed the following sequence $T$. vogelii $>M$. charantia $>$ A. conyzoides.

The result for percentage mortality of $R$. dominica due to exposure to different doses of the powders from the three test plants is shown in

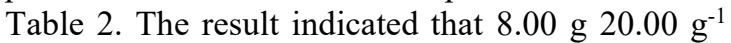
of the powders obtained from Ageratum conyzoides, Momordica charantia and Tephrosia vogelii induced more than 50\% mortality with mortality rate of $58.70 \%, 63.50 \%$ and $77.30 \%$ respectively. The percentage mortality increased with increase in dosage.

The result for the percentage inhibition of oviposition and progeny development induced by various doses of the plants powders is presented in Table 3 . The result revealed significant differences $(p \leq 0.05)$ in the mean number of eggs laid and adult emergence among the treatments. The result showed that, 28 to 65 eggs were laid in $A$. conyzoides treated grains out of which 11 to 39 adults emerged representing $38-59.75 \%$ adult emergence with decreased dosage. The number of eggs laid by the insects on grains treated with $M$. charantia was 31-67 eggs out of which 33.38$51.08 \%$ adults emerged with decreased dosage. More so, 18-53 eggs were laid on T. vogelii treated grains out of which $28.55-49.72 \%$ adults emerged with decrease in dosage. However, the highest percentage progeny development inhibition was

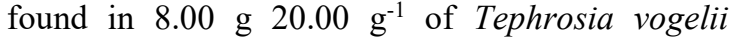
powder in which only $28.55 \%$ emerged as adults while the remaining $71.45 \%$ were inhibited. Similarly, the least number of eggs laid and the percentage adult emergence were found under $8.0 \mathrm{~g}$ $20.00 \mathrm{~g}^{-1}$ of the other two test plants powders. The number of eggs laid and the percentage of adult emergence decreased with increase dosage.

The result for the average mean percentage damage induced by $R$. dominica on the treated wheat grains is shown in Table 4. Insect damage on wheat grains treated with various doses of $T$. vogelii powders for a period of six months reduced from $4.17 \%$ to as low as $0.35 \%$ with increased dosage. These values are significantly lower than that of the control $(9.12 \%)$. More so, the grains treated with $M$. charantia powders reduced the infestation rate from $5.14 \%$ to as low as $0.96 \%$ with increased dosage. Similar result was found in grains treated with $A$. conyzoides powders (the infestation rate reduced from $6.14 \%$ to as low as $1.15 \%$ ) with increase in dose. Complete protection of the grains for a period of three months was found in $8.00 \mathrm{~g}$ $20.00 \mathrm{~g}^{-1}$ dose obtained from $T$. vogelii while the remaining powders gave full protection for a period of two months by the higher doses.

Table 1: Relative toxicity of various plant powders on Rhyzopertha dominica

\begin{tabular}{lcccccc}
\hline Plant powders & $24 \mathrm{hr} \mathrm{LD}_{50}\left(\mathrm{~g} 20.00 \mathrm{~g}^{=1}\right)$ & $95 \% \mathrm{CL}$ & $\mathrm{TF}$ & $48 \mathrm{hr} \mathrm{LD}_{50}$ & $95 \% \mathrm{CL}$ \\
\hline Ageratum conyzoides & 20.09 & - & 1.63 & 15.48 & - & $\mathrm{TF}$ \\
Momordica charantia & 18.69 & - & 1.51 & 12.36 & - \\
Tephrosia vogelii & 12.74 & - & 1.03 & 9.58 & - \\
\hline
\end{tabular}

$\mathrm{TF}$ - test of significance; CL - confidence limit; TF - $\mathrm{LD}_{50}$ values with no overlap in $95 \%$ confidence limits are significantly different

Table 2: Mortality of Rhyzopertha dominica due to exposure to treated grains with powders of plants

\begin{tabular}{|c|c|c|c|c|c|c|}
\hline Powdered extract & $0.00 \mathrm{~g}$ & $0.50 \mathrm{~g}$ & $1.00 \mathrm{~g}$ & $2.00 \mathrm{~g}$ & $4.00 \mathrm{~g}$ & $8.00 \mathrm{~g}$ \\
\hline Ageratum conyzoides & $0.00^{\mathrm{a}^{*}}$ & $28.00^{\mathrm{b}}$ & $38.00^{\mathrm{c}}$ & $49.40^{\mathrm{b}}$ & $52.90^{\mathrm{b}}$ & $58.70^{\mathrm{c}}$ \\
\hline Momordica charantia & $0.00^{\mathrm{a}}$ & $35.00^{\mathrm{bc}}$ & $43.00^{\mathrm{b}}$ & $53.60^{\mathrm{bc}}$ & $56.20^{\mathrm{bc}}$ & $63.50^{\mathrm{b}}$ \\
\hline Tephrosia vogelii & $0.00^{\mathrm{a}}$ & $38.00^{\mathrm{a}}$ & $51.50^{\mathrm{a}}$ & $62.30^{\mathrm{a}}$ & $68.90^{\mathrm{a}}$ & $77.30^{\mathrm{a}}$ \\
\hline
\end{tabular}

N.B: *Mean values bearing the same letter(s) down a column are not significantly different $(p=0.05)$ 
Table 3: Oviposition and progeny development of Rhyzopertha dominica on wheat rains

\begin{tabular}{|c|c|c|c|c|}
\hline Plant powder & Dose $\left(\mathrm{g} 20.00 \mathrm{~g}^{-1}\right)$ & Number of eggs laid & Adult emergence (\%) & Percent adult emergence (\%) \\
\hline \multirow[t]{5}{*}{ Ageratum conyzoides } & 0.00 & $89.76^{\mathrm{a}^{*}}$ & $87.60^{\mathrm{a}}$ & 97.59 \\
\hline & 1.00 & $65.14^{\mathrm{b}}$ & $38.92^{\mathrm{b}}$ & 59.75 \\
\hline & 2.00 & $51.33^{\mathrm{c}}$ & $24.88^{\mathrm{c}}$ & 53.84 \\
\hline & 4.00 & $46.21^{\mathrm{d}}$ & $21.32^{\mathrm{d}}$ & 46.17 \\
\hline & 8.00 & $28.26^{\mathrm{e}}$ & $10.74^{\mathrm{e}}$ & 38.00 \\
\hline \multirow[t]{5}{*}{ Momordicacharantia } & 0.00 & $90.01^{\mathrm{a}}$ & $86.36^{\mathrm{a}}$ & 95.94 \\
\hline & 1.00 & $67.21^{\mathrm{b}}$ & $34.33^{\mathrm{b}}$ & 51.08 \\
\hline & 2.00 & $58.11^{\mathrm{c}}$ & $25.79^{\mathrm{c}}$ & 44.38 \\
\hline & 4.00 & $52.00^{\mathrm{d}}$ & $21.82^{\mathrm{d}}$ & 41.96 \\
\hline & 8.00 & $30.73^{\mathrm{e}}$ & $10.26^{\mathrm{e}}$ & 33.38 \\
\hline \multirow[t]{5}{*}{ Tephrosia vogelii } & 0.00 & $89.73^{\mathrm{a}}$ & $83.79^{\mathrm{a}}$ & 93.38 \\
\hline & 1.00 & $52.45^{\mathrm{b}}$ & $26.08^{\mathrm{b}}$ & 49.72 \\
\hline & 2.00 & $40.32^{\mathrm{c}}$ & $18.90^{\mathrm{c}}$ & 46.88 \\
\hline & 4.00 & $35.11^{\mathrm{d}}$ & $13.05^{\mathrm{d}}$ & 37.17 \\
\hline & 8.00 & $18.25^{\mathrm{e}}$ & $5.210^{\mathrm{e}}$ & 28.55 \\
\hline
\end{tabular}

Key: * Means bearing the same superscripts down a column are not significantly different $(\mathrm{p}=0.05)$

Table 4: Percentage mean damage by Rhyzopertha dominica on treated wheat grains

\begin{tabular}{|c|c|c|c|c|c|c|c|}
\hline Plant powder & Month & $0.00 \mathrm{~g}$ & $0.50 \mathrm{~g}$ & $1.00 \mathrm{~g}$ & $2.00 \mathrm{~g}$ & $4.00 \mathrm{~g}$ & $8.00 \mathrm{~g}$ \\
\hline \multirow[t]{7}{*}{ Ageratum conyzoides } & $1^{\text {st }}$ & $1.86^{\mathrm{a}}$ & $0.00^{\mathrm{a}}$ & $0.00^{\mathrm{a}}$ & $0.00^{\mathrm{a}}$ & $0.00^{\mathrm{a}}$ & $0.00^{\mathrm{a}}$ \\
\hline & $2^{\text {nd }}$ & $6.52^{\mathrm{a}}$ & $0.00^{\mathrm{b}}$ & $0.00^{\mathrm{b}}$ & $0.00^{\mathrm{b}}$ & $0.00^{\mathrm{b}}$ & $0.00^{\mathrm{b}}$ \\
\hline & $3^{\text {rd }}$ & $9.23^{\mathrm{a}}$ & $3.65^{b}$ & $2.73^{\mathrm{c}}$ & $2.08^{\mathrm{c}}$ & $1.76^{\mathrm{c}}$ & $0.71^{\mathrm{d}}$ \\
\hline & $4^{\text {th }}$ & $14.01^{\mathrm{a}}$ & $5.04^{\mathrm{b}}$ & $4.26^{\mathrm{c}}$ & $3.14^{\mathrm{d}}$ & $1.82^{\mathrm{de}}$ & $1.07^{\mathrm{e}}$ \\
\hline & $5^{\text {th }}$ & $17.37^{\mathrm{a}}$ & $11.00^{\mathrm{b}}$ & $8.81^{\mathrm{c}}$ & $4.65^{d}$ & $2.13^{\mathrm{e}}$ & $1.88^{\mathrm{f}}$ \\
\hline & $6^{\text {th }}$ & $25.26^{\mathrm{a}}$ & $17.14^{\mathrm{b}}$ & $13.13^{\mathrm{c}}$ & $8.21^{\mathrm{d}}$ & $5.24^{\mathrm{e}}$ & $3.23^{\mathrm{f}}$ \\
\hline & Mean & 12.38 & 6.14 & 4.82 & 3.01 & 1.83 & 1.15 \\
\hline \multirow[t]{9}{*}{ Momordica charantia } & $1^{\text {st }}$ & $1.74^{\mathrm{a}}$ & $0.00^{\mathrm{b}}$ & $0.00^{\mathrm{b}}$ & $0.00^{\mathrm{b}}$ & $0.00^{\mathrm{b}}$ & $0.00^{\mathrm{b}}$ \\
\hline & $2^{\text {nd }}$ & $5.21^{\mathrm{a}}$ & $0.00^{\mathrm{b}}$ & $0.00^{\mathrm{b}}$ & $0.00^{\mathrm{b}}$ & $0.00^{\mathrm{b}}$ & $0.00^{\mathrm{b}}$ \\
\hline & $3^{\text {rd }}$ & $7.16^{\mathrm{a}}$ & $3.11^{\mathrm{b}}$ & $2.89^{\mathrm{bc}}$ & $2.00^{\mathrm{c}}$ & $1.56^{\mathrm{d}}$ & $0.56^{\mathrm{e}}$ \\
\hline & $4^{\text {th }}$ & $12.92^{\mathrm{a}}$ & $4.52^{b}$ & $3.78^{\mathrm{c}}$ & $2.26^{\mathrm{d}}$ & $1.70^{\mathrm{e}}$ & $0.89^{f}$ \\
\hline & $5^{\text {th }}$ & $15.52^{\mathrm{a}}$ & $9.17^{\mathrm{b}}$ & $5.43^{\mathrm{c}}$ & $3.18^{\mathrm{d}}$ & $2.00^{\mathrm{e}}$ & $1.45^{\mathrm{f}}$ \\
\hline & $6^{\text {th }}$ & $22.17^{\mathrm{a}}$ & $14.06^{\mathrm{b}}$ & $11.85^{\mathrm{c}}$ & $6.28^{\mathrm{d}}$ & $4.12^{\mathrm{e}}$ & $2.85^{\mathrm{f}}$ \\
\hline & Mean & 10.79 & 5.14 & 3.99 & 2.29 & 1.56 & 0.96 \\
\hline & $1^{\text {st }}$ & $1.69^{\mathrm{a}}$ & $0.00^{\mathrm{b}}$ & $0.00^{\mathrm{b}}$ & $0.00^{\mathrm{b}}$ & $0.00^{\mathrm{b}}$ & $0.00^{\mathrm{b}}$ \\
\hline & $2^{\text {nd }}$ & $4.54^{\mathrm{a}}$ & $0.00^{\mathrm{b}}$ & $0.00^{\mathrm{b}}$ & $0.00^{\mathrm{b}}$ & $0.00^{\mathrm{b}}$ & $0.00^{\mathrm{b}}$ \\
\hline \multirow[t]{5}{*}{ Tephrosia vogelii } & $3^{\text {rd }}$ & $6.23^{\mathrm{a}}$ & $2.15^{\mathrm{b}}$ & $0.76^{\mathrm{c}}$ & $0.27^{\mathrm{cd}}$ & $0.04^{\mathrm{d}}$ & $0.00^{\mathrm{e}}$ \\
\hline & $4^{\text {th }}$ & $10.16^{\mathrm{a}}$ & $3.68^{\mathrm{b}}$ & $1.44^{\mathrm{c}}$ & $0.98^{\mathrm{d}}$ & $0.26^{\mathrm{e}}$ & $0.08^{\mathrm{f}}$ \\
\hline & $5^{\text {th }}$ & $13.25^{\mathrm{a}}$ & $6.92^{\mathrm{b}}$ & $3.91^{\mathrm{c}}$ & $2.83^{d}$ & $1.89^{\mathrm{e}}$ & $0.95^{\mathrm{f}}$ \\
\hline & $6^{\text {th }}$ & $18.84^{\mathrm{a}}$ & $12.27^{\mathrm{b}}$ & $9.85^{\mathrm{c}}$ & $5.94^{\mathrm{d}}$ & $3.64^{\mathrm{e}}$ & $1.04^{\mathrm{f}}$ \\
\hline & Mean & 9.12 & 4.17 & 2.66 & 1.67 & 0.97 & 0.35 \\
\hline
\end{tabular}

Key: ${ }^{11}$ Means bearing the same superscripts across a row are not significantly different $(\mathrm{p}=0.05)$

\section{DISCUSSION}

Botanical pesticides have proved vital in insect pests' management strategies. These botanicals serve as alternatives to commercially used synthetic insecticides and many of them have often been used against a number of species of stored product insect pests including those in the Order Coleoptera and Lepidoptera (Nathan et al., 2007). The three powders obtained from Ageratum conyzoides, Momordica charantia and Tephrosia vogelii proved to possess insecticidal potency for the protection of stored wheat grains against $R$. dominica infestation. The relative toxicity of the powders on $R$. dominica after 48 hours of exposure agrees with the findings of Ahmad et al. (2016) who reported similar finding with Pipernigrum extracts on $R$. dominica but after 120 hours of application. The present study reported highest percentage mortality induced by higher doses of the plants powders. This is in conformity with the findings of Alvi et al. (2018) who reported high mortality induced by the leaf and seed extracts of Rhazya stricta on Rhyzopertha dominica and Trogoderma granarium under laboratory conditions. The powders conferred certain degrees of toxicity to the insect by inhibiting more than $50 \%$ of the eggs laid and suppressed progeny development. This finding agrees with that of Ogendo et al. (2004) who reported more than $50 \%$ induced mortality by Tephrosia vogelii extracts on Sitophilus zeamais. Similar finding was also reported by Babarinde et al. (2001) that leaf and seeds powders of Piper guineense and Moringa oleifera were effective showed effective bioactivity against Trogoderma granarium. Adebayo (2003) also reported insecticidal activity of botanical insecticides in the control of insect pests of okra and cowpea. Also, dried leaves of T. vogelii were reported by Koona and Dorn (2005) to be effective protestants of stored legume seeds against bruchid infestation and reduced damage by Callosobruchus maculatus. C. chinensis and Acanthosceli desobstectus on the treated seeds by $7.10 \%$ compared with $99.80 \%$ recorded on grains in the control experiment. Similarly, Ileke and Bulus (2012) reported toxicity of powders and extracts of Azadirachta indica and Piper guineense seeds to $R$. dominica as reported by this study. Furthermore, botanical extracts have been reported by Amuji et al. (2012) to exhibit appreciable magnitude of toxicity to 
insects inducing mortality. Ousman et al. (2007) has reported that Piper nigrum leaf oil was toxic to stored insect pests and concluded that the extract be used as a substitute for synthetic insecticides by small scale farmers. The toxicity of the three plant extracts revealed by this study has therefore confirmed the previous findings of Oumarou et al. (2017) who reported the bioefficacy of plants extracts on Anopheles gambiae, Cheruvan and Ragesh (2018) has reported insecticidal effects of cassava leaf extracts against Sitophilus oryzae (L.), Rhyzopertha dominica (F.), Tribolium castaneum (Herbst) and Callosobruchus chinensis (L.) under laboratory conditions whilst Ileke and Emmanuel (2018) reported high bioefficacy of Alstonia boonei leaf extract against the cowpea beetle (Callosobruchus maculatus) infestation of stored cowpea seeds. The toxicity of the plants powders can probably be attributed to the various chemical constituents present in the extracts (Mbailao et al., 2006).

The effect of the three powders reported by the present study in suppressing progeny development and oviposition of $R$. dominica can be attributed to the toxicity and lethality conferred on the insects thereby interfering with physiological processes of eggs development. This finding is in conformity with the report of Osawe et al. (2007) which opined that extracts of Alstonia boonei leaves adversely affected the survival and growth of Sesamia calamistis. Upadhyay and Jaiswal (2007) also reported that botanical insecticides significantly suppressed the progeny development of Tribolium castaneum. Chaubey (2011) averred that $P$. nigrum oil reduced the progeny development of Callosobruchus chinensis. The powders reported by this study might probably possess certain chemicals that could be responsible for the inability of the adult insects to emerge, as they are found to disrupt growth and reduce larvae survival as well as disruption of life cycle of insects. Mukanga et al. (2010) has earlier reported the suppression of progeny development of larger grain borer (Prostephanus truncatus) by $T$. vogelli extracts. The inability of these insects to emerge may be due to the death of the insect's larvae, which may occur due to inability of the larvae to fully cast off their exoskeleton, which remained linked to the posterior part of their abdomen. This agrees with the observation by Oigiangbe et al. (2010) who worked on insecticidal properties of an alkaloid from Alstonia boonei. The growth inhibition may result from toxicity or feeding deterrent properties of the plant powders used in this study. Akhtar and Isman (2004), Erturk (2006) and Suleiman et al. (2018) reported the insecticidal efficacy of some plant extracts in suppressing progeny development of stored insect pests.

The protection ability of the three plants powders reported by this study is in agreement with the work of Chikukura et al. (2011) who reported the potency of Lippia javanica in reducing the grain damage caused by storage pests. Duruigbo (2010) also reported that need and pepper fruit seed powders protected maize seed from damage by storage insects when stored in airtight plastic containers without affecting the seed viability. Similar finding was reported by Iliyasu and Gabriella (2015). The toxicity of the three plants powders on the test organism is an indication of the relative importance of the powders in preventing the wheat grains from damage by $R$. dominica infestation. This is in conformity with the work of Adeniyi et al. (2010) who reported that plant extracts obtained from Vernonia amygdalina, Sida acuta, Osmium gratissimum and Telfaria occidentalis were effective against beans weevil. This finding therefore adds to the existing data on the efficacy of plant extracts as biopesticides of stored food.

\section{CONCLUSION AND RECOMMENDATION}

Powdered extracts from the leaves of Ageratum conyzoides, Momordica charantia and Tephrosia vogelii were found to possess insecticidal potency against Rhyzopertha dominica by inducing 28 $77.30 \%$ mortality of the insects. The effect of the powders on the mortality of $R$. dominica was dose dependent, increasing with increase in dosage rates. The powders also suppress progeny development of the insects from $97.57 \%$ to as low as $28.55 \%$. The plants powders were also found to protect wheat grains from the insect's infestation for a period of 6 months. The sequence of insecticidal activity of the three powders is as follows: $T$. vogelii $>M$. charantia $>A$. conyzoides.

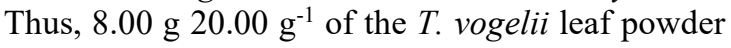
is highly recommended for biological control of $R$. dominica in stored wheat grains.

\section{REFERENCES}

Adda C., Atachi P., Hell K. and Tamò M. (2011). Potential use of the bushmint, Hyptis suaveolens, for the control of infestation by the pink stalk borer, Sesamia calamistis on maize in Southern Benin, West Africa. J. Insec. Sci., 11 (33), 1-13

Adebayo T.A. (2003). Efficacy of mixture formulations of synthetics and botanical insecticides in the control of insect pests of okra and cowpea. Ph.D. Thesis submitted to Ladoke Akintola University of Technology, Ogbomoso, Nigeria 154-169

Adedire C.O. (2001). Pests of stored cereals and pulses in Nigeria. In: T.I. Ofuya and N.E.S. Lale (eds.), Biology, Ecology and Control of Insect Pests of Stored Grains. Dave Collins publication, Nigeria. pp. 59-94

Adedire C.O. and Lajide, L. (2003). Ability of extract of ten tropical plant species to protect maize grains against infestation by the maize weevil Sitophilus zeamais during storage. Nig. J. Expt. Biol., 4 (2), 175-179

Adedire C.O., Obembe O.O., Akinkurolele, R.O. and Oduleye, O. (2011). Response of Callosobruchus maculatus (Coleoptera: Chysomelidae: Bruchinae) to extracts of cashew kernels. J. Pl. Dis. Prot., 118 (2), 75-79 
Adeniyi S.A., Orjiekwe C.L., Ehiagbonare J.E. and Arimah B.D. (2010). Preliminary phytochemical analysis and insecticidal activity of ethanolic extracts of four tropical plants (Vernonia amygdalina, Sida acuta, Osmium gratissimum and Telfaria occidentalis) against beans weevil (Acanthoscelidesobtectus). Intl. J. Phys. Sci., 5 (6):753-762

Ahmad I., Mansoor-ul-Hasan, Arshad M.R. et al. (2016). Efficacy of different medicinal plant extracts against Rhyzopertha dominica (Fabr.) (Bostrichidae: Coleoptera). J. Entomol. Zool. Stud., 4 (6), 87-91

Akhtar Y. and Isman, M.B. (2004). Comparative growth inhibitory and anti feedant effect of plant extract and pure allelochemical on four phytophagus insect species. J. Appl. Entomol., 128 (1), 32-38

Akinkurolere R.O., Sebastien B., Haoliang C. and Hongyu Z. (2009). Parasitism and host location preference in Habrobracon hebetor (Hymenoptera: Braconidae): Role of refuge, choice and host instar. J. Econ. Entomol., 102 (2), 610-615

Alvi A.M., Iqbal N., Bashir M.A., Rehmani M.I.A., Ullah Z., Seed Q. and Latif A. (2018). Efficacy of Rhazya stricta leaf and seed extracts against Rhyzopertha dominica and Trogoderma granarium. Kuw. J. Sci., 45 (3), 54-71

Amuji C.F., Echezona B.C. and Dialoke S.A. (2012). Extraction of fractions of ginger (Zingiber officinale Roscoe) and residue in the control of field and storage pests. J. Agric. Vet. Sci., 4 (2012), 45-52

Ashamo M.O, and Odeyemi O.O. (2001). Protection of maize against Sitophilus zeamais using seed extracts from some indigenous plants. J.Pl. Dis. Prot., 108 (3), 321-326

Babarinde S.A., Pitan O.R. and Ogunfiade A.T. (2001). Bioactivity of Piper guineense Schum and Thonn seed and Moringa oleifera Lam. leaf powder against Trogoderma granarium Evert (Coleoptera: Dermestidae). Arch. Phytopathol. Plant Prot., 44 (3), 298-306

Chaubey M.K. (2011). Combinatorial action of essential oils towards pulse beetle Callosobruchus chinensis Fabricius (Coleoptera: Bruchidae). Intl. J. Agric. Res., $6(6), 1-6$

Cheruvan A.J. and Ragesh L. (2018). Toxicity of extracts derived from different parts of cassava plant, Manihot esculenta Crantz to four major coleopteran pests of stored-products. $12^{\text {th }}$ International Working Conference on Stored Product Protection (IWCSPP) in Berlin, Germany, October 7-11, pp. 851-855

Chikukura L., Mvumi B., Chikonzo R. and Chenzara C. (2011). Evaluation of selected indigenous pesticidal plant powders against stored maize and cowpeas insect pests. Proceedings of the African Crop Science Conference, 10, 189-192, Maputo, Mozambique

Dabire C., Ba M.N. and Sanon A. (2008). Effects of crushed fresh Cleome viscosa L. (Capparaceae) plants on the cowpea storage pest, Callosobruchus maculatus Fab. (Coleoptera: Bruchidae). Intl. J. Pest Mgt., 54, 319-326

Dabire C.L.B., Kini F.B., Ba M.N., Dabire R.A. and FouaBi K. (2005). Effet du stade de development des gousses de niebe sur la biologie de la punaise suceuse Clavigralla tomentosicollis Stl. (Hemiptera: Coreidae). Intl. J. Trop. Ins. Sci., 25, 25-31

Duruigbo C.I. (2010). Assessing the viability of maize and cowpea seeds stored using local plant biocides. New York Sci. J., 3, 1-3
Emeasor K.C. and Ndumele P.N. (2019). Comparative toxicity of aqueous extract of Tephrosia vogelii and some synthetic insecticides in the control of insect pests of cucumber (Cucumis sativus L.). Greener Trends in Pl. Pathol. Entomol., 2 (1), 1-8

Erturk O. (2006). Antifeedant and toxicity effects of some plants extract on Thaumetopioae solitaria Frey (Lepidoptera: Thaumetopoeidae) Turk. J. Biol., 3, 51-57

Fornal J., Jelinski T., Sadowska J. et al. (2007). Detection of granary weevil Sitophiilus granaries L., eggs and internal stage analysis. J. Stored Prod. Res., 43, 142-148

Ileke K.D. (2011). Effect of Sitophilus zeamais Mot. and $S$. oryzae (L.) [Coleoptera: Curculionidae] infestation on grain quality of wheat (Triticum aestivum). J. Phys. Biol. Sci., 4 (1), 7-12

Ileke K.D. and Oni M.O. (2011). Toxicity of some plant powders to maize weevil, Sitophilus zeamais (Coleoptera: Curculionidae) on stored wheat grains. Afr. J. Agric. Res., 6 (13), 3043-3048

Ileke K.D. and Olotuah O.F. (2012). Bioactivity of Anacardium occidentalis and Allium sativum powders and oils extracts against cowpea bruchid, Callosobruchus maculatus (Fab) [Coleoptera: Chrysomelidae]. Intl. J. Biol., 4 (1), 96-103

Ileke K.D. and Bulus D.S. (2012). Evaluation of contact toxicity and fumigant effect of some medicinal plant and pirimiphos methyl powders against cowpea bruchid, Callosobruchus maculatus (Fab) [Coleoptera: Chrysomelidae] in stored cowpea seeds. J. Agric. Sci., 4 (4), 279-284

Ileke K.D., Odeyemi O.O. and Ashamo M.O. (2012). Insecticidal activity of Alstonia boonei De Wild powder against cowpea bruchid, Callosobruchus maculatus (F.) (Coleoptera: Chrysomelidae) in stored cowpea seeds. Intl. J. Biol., 4 (2), 125-131

Ileke K.D. and Emmanuel A.T. (2018). Bioefficacy of Alstonia boonei leaf extract against cowpea beetle Callosobrochus maculatus infesting stored cowpea seeds in storage. Braz. J. Biol. Sci., 5 (11), 673-681

Iliyasu M.U. and Gabriella G. (2015). New stimuli enriched laboratory bioassay used to identify improved botanical repellent treatment Lemocimum, to control the stored grain pest Tribolium castaneum. J. Stored Prod. Res., 64, 27-35

Jood S. and Kapoor A.C. (1993). Effect of storage and insect infestation on protein and starch digestibility of cereal grains. Food Chem., 44, 209-212

Jood S., Kapoor A.C. and Singh R. (1996). Effect of infestation and storage on lipids of cereals. J. Agric. Food Chem., 44 (6), 1502-1506

Kavita H.N. (2004). Abiotic and biotic factors affect efficacy of chlorfenapyral for control of storedproduct insect pests. J. Food Prot., 74 (8), 1288-1299

Koona P. and Dorn S. (2005). Extracts from Tephrosia vogelii for the protection of stored legume seeds against damage by three chid species. Ann. Appl. Biol., 147 (1), 43-48

Mbailao M., Nanadoum M., Automne B., Gabra B. and Emmanuel A. (2006). Effect of six common seed oils on survival, egg lying and development of the cowpea weevil, Callosobruchus maculatus. J. Biol. Sci., 6 (2), 420-25

Mukanga M., Deedat Y. and Mwangala F.S. (2010). Toxic effects of five plant extracts against the larger grain borer, Prostephanus truncatus. Afr. J. Agric. Res., 5 (24), 3369-3378 
Nathan S.S., Choi M., Paik C. and Seo H. (2007). Food consumption, utilization and detoxification enzyme activity of the rice leaf folder larvae after treatment with Dysoxylum triterpenes. Pestic. Biochem. Physiol., 88, 260-267

Odeyemi O.O. and Daramola A.M. (2000). Storage Practices in the Tropics: Food Storage and Pest Problems. First Edition, Dave Collims Publication, Nigeria, 2, 235

Ogendo J.O., Deng A.L., Belmain S.R., Walker D.J. and Musandu A.O. (2004). Effect of insecticidal plant materials, Lantana camara L. and Tephrosia vogelii Hook, on the quality parameters of stored maize grains. J. Food Tech. Afr., 9, 29-35

Oigiangbe O.N., Igbinosa I.B. and Tamo M. (2010). Insecticidal properties of an alkaloid from Alstonia boonei De Wild. J. Biopest., 3 (1), 265-270

Olaniran O.A. and Adebayo T.A. (2013). Control of foliage pests of roselle (Hibiscus sadbariffa L.) using plant extracts of Tephrosia vogelii and Azadirachta indica in Ogbomosho, Nigeria. Trans. J. Sci. Tech., 3 (6), 51-62

Oni M.O. and Ileke K.D. (2008). Fumigant toxicity of four botanical plant oils on survival, egg laying and progeny development of the dried yam beetle, Dinoderus porcellus (Coleoptera: Bostrichidae). Ibadan J. Agric. Res., 4 (2), 31-36

Osawe N.O., Igho B.I. and Manuele T. (2007). Insecticidal activity of the medicinal plant, Alstonia boonei against Sesamia calamistis Hampson. J. Zhejiang Univ., 8 (10), 752-755

Oumarou M.K., Younoussa L. and Nukenine E.N. (2017). Toxic effect of Chenopodium ambrosoides, Hyptis suaveolens and Lippia adoensis leaf methanol extracts and essential oils against fourth instar larvae of Anopheles gambiae (Diptera: Culicidae). Intl J. Mosq. Res., 5 (1), 61-66
Ousman A., Ngassoum M.B., Essia-Ngang J.J., Ngamo L.S.T. and Ndjouenkeu R. (2007). Insecticidal activity of spicy plant oils against Sitophilus zeamais in stored maize in Cameroon. J. Agric., 2 (2), 192-196

Raju P. (1984). The staggering storage losses-causes and extent. Pest., 18, 35-37

Salem S.A., Abou-Ela R.G., Matter M.M. and El-Kholy M.Y. (2007). Entomocidal effect of Brassica napus extracts on two store pests, Sitophilus oryzae (L.) and Rhizopertha dominica (Fab.) (Coleoptera). J. Appl. Sci. Res., 3, 317-322

Singh P. and Jakhmola S.S. (2011). Efficacy of botanical extracts on biological activities of pulse beetle Callosobruchus maculatus (Fab.) on green gram. Trends Biosci., 4 (1), 25-30

Strbac P. (2002). Štetocine uskladištenih proizvoda i njihova kontrola. Poljoprivredni fakultetNovi sad, Institut za zašstitu bilja i životne sredine Dr. Pavle Vuksanovic, Stamparija Feljton Novi. Sad., 42 (47), 174-176

Subramanyam B.H. and Hagstrum D.W. (1996). Resistance measurements and managements. In: B. Subramanyam, D.W. Hagstrum, (eds.), Integrated Management of Insects in Stored Products. Marcel Dekker, New York, pp. 331-389

Suleiman M., Rugumamu C.P. and Ibrahim N.D. (2018). Use of botanicals to suppress the development of maize weevil, Sitophilus zeamais Motsch. (Coleoptera: Curculionidae) in stored sorghum grains. J. Agric. Vet. Sci., 11 (2), 1-10

Udo I.O. (2011). Potential of Zanthoxylum xanthoxyloides (Lam.) for the control of stored product insect pests. J. Stored Prod. Posthav. Res., 2 (3), 40-44

Upadhyay R.K. and Jaiswal G. (2007). Evaluation of biological activities of Piper nigrum oil against Tribolium castaneum. B. Insectol. 60 (1), 57-61 